\title{
European Journal of
} Women's Studies

\section{Hating men will free you? Valerie Solanas in Paris or the discursive politics of misandry}

\begin{tabular}{|c|c|}
\hline Journal: & European Journal of Womens Studies \\
\hline Manuscript ID & EJW-20-0088.R1 \\
\hline Manuscript Type: & Original Article \\
\hline Keywords: & $\begin{array}{l}\text { Misandry, Feminist Theory, Mouvement de Libération des Femmes, } \\
\text { Respectability politics, Valerie Solanas, Hatred }\end{array}$ \\
\hline Abstract: & $\begin{array}{l}\text { In the wake of contemporary controversies in France over feminist } \\
\text { misandry (Coffin 2020, Harmange 2020), this article reflects on claimed } \\
\text { hatred of men as a feminist discursive resource. I use the reception of } \\
\text { Valerie Solanas' SCUM Manifesto by some radical French feminists of the } \\
1970 \text { s as a priviledged case study, along with historian Colette Pipon's } \\
\text { study on misandry within French second wave feminist movements and } \\
\text { Judith Butler's works on stigma reversal. I contend that in a seemingly } \\
\text { paradoxical way misandry is both an anti-feminist stigma and a feminist } \\
\text { discursive strategy: the inhibiting effects of such injurious term on } \\
\text { feminist politics - the aggressive, castrating and hateful feminist you } \\
\text { should at all cost avoid to become - can be managed, if not neutralized, } \\
\text { by means of feminist misandry. From that point, I argue that claimed } \\
\text { hatred of men can open fruitful political venues in challenging the stifling } \\
\text { effects of respectability politics. }\end{array}$ \\
\hline
\end{tabular}

\section{SCHOLARONE Manuscripts}




\title{
Hating men will free you? Valerie Solanas in Paris or the discursive politics of misandry
}

\begin{abstract}
Introduction
In September 2020, a small independent French publishing house issued a manifesto straightforwardly entitled I Hate Men (Moi, les hommes, je les déteste), written by Pauline Harmange, a young feminist blogger and activist (Harmange, 2020). Ralph Zuméry, an employee of the French Ministry of Gender Equality, approached the publishing house on his own initiative, charged the book with hate speech and urged the publisher to take it off the market (Cappelle, 2021). This attempt immediately set the 'Streisand effect' in motion: within a few weeks, the initially confidential manifesto was acquired by a major publishing house, reprinted in large volumes and translated into several languages. ${ }^{1}$ Soon thereafter, journalist, ecologist and Paris city councillor Alice Coffin published an essay - Lesbian Genius - which she says she seriously considered titling 'misandre' (man-hater) (Coffin, 2020: p. 10), and in which she unapologetically claims her distrust of men. These two cases share more than one commonality. Both authors claim misandry as integral part of their feminism, and, paradoxically, their statements were largely popularized by the vehemence of their anti-feminist opponents' attacks. They brought the issue of hatred of men to the forefront, inspiring an outrage that highlighted the close and complex intertwining of feminist misandry and reactionary discourses.
\end{abstract}

What does it mean when feminists claim misandry? How can we analyse violent feelings when directed by an oppressed group (women) against a structurally dominant group (men)? I approach this issue by looking at a historical and archetypal case, the reception of Valerie Solana's SCUM Manifesto in France. In doing so, I aim at filling a gap in feminist studies: while emotions are a privileged field of inquiry, hate has been given little attention and its role in feminist movements is relatively unexplored. The few works on the issue tend to emphasize its reactionary dimension by focusing on hatred of minorities, be they racial, sexual, gender, etc. The contrast is striking, as similar feelings such as anger have received a lot of coverage (Holmes, 2004; Lorde, 1984b; Spelman, 1996; Ahmed, 2013). In spite of many feminists' legitimate reluctance to investigate such an 'ugly feeling' (Ngai, 2005), I argue that claimed hatred against men is worth studying. With hatred, I aim to bring an original perspective to feminist affect studies, drawing inspiration from the already well-documented negative turn in queer studies that has occurred in the last two decades (Halberstam, 2011).

This article aims at clarifying the possibilities, limits and implications of the uses of hatred as a discursive resource by feminists. My discussion, although ultimately theoretical, is based on an empirical inquiry into the reception of Valerie Solanas' SCUM Manifesto within the French feminist movements of the 1970s. As a feminist theorist, I aim at taking the case of Solanas' reception in France as a privileged case study for an investigation on the signification of hatred in feminist discourses, and to assess the role of feminist misandry for feminism from a normative perspective. To that end, I use press articles of the 1970s from French feminist journals and works of historians. What are the effects of Solanas' speeches about hating men on feminist movements? What possibilities can such a discourse offer to feminism and which ones does it foreclose?

1 The English translation by Natasha Lehrer was released in November 2020. See Harmange and Lehrer (2020). 
I will first examine the reasons for feminists' reluctance to talk about their negative feelings about men and show that misandry is first and foremost an anti-feminist stigma feminists have to contend with. Then, I will raise the issue of feminist anti-men hate discourses - how should we understand and interpret the discourses of feminists like Harmange or Coffin who actually claim to hate men? Drawing from Judith Butler's work on stigma reversal I will show that such speeches can be read as discursive strategies. I will then further this hypothesis discussing the work of historian Colette Pipon on misandry in the French feminist movements in the 1970s, paying special attention to the reception of Solanas' SCUM Manifesto. Finally, I argue that, as a contextual discursive strategy, man-hating discourses can open fruitful political venues in challenging the stifling effects of respectability politics, which may explain their enduring appeal among contemporary feminists.

\section{Thinking what feminists do not want to think: toward a negative turn in feminist affect studies}

Feminists have been reluctant to explore the links between feminism and hatred. This reluctance may first be linked to the problematic role hatred is usually associated with in politics, namely the many forms of hatred towards minorities - racial hatred, anti-Semitism, homophobia, misogyny, etc.; what I will call here reactionary hatred. Audre Lorde thus assesses that contrary to anger, hatred is fundamentally a destructive feeling directed by oppressors towards those they oppress; a 'virulent' affect against 'women, people of Color, lesbians and gay men, poor people' (Lorde, 1984b: p. 128). As a progressive movement, feminism seems at odds - or feminists may like to think it at odds - with such hate expressed against oppressed groups.

Moreover, hatred appears highly essentializing. It consists in a desire to harm others that, contrary to anger, does not focus on specific acts or interactions but rather on the individual or group as a whole. Sarah Ahmed describes the way hatred results in turning the mere existence of marginalized racialized bodies into an injury to the 'ordinary white subject'. Hatred, she argues, is part of a social narrative that 'works by generating a subject that is endangered' and threatened by the sole 'proximity' of 'imagined others' (Ahmed, 2013: pp. 42-43). Hatred then takes on an ontological dimension - it is directed towards someone's whole being rather than their deeds. In his philosophical work on the role of hatred in politics, Oliver Le Cour Grandmaison assesses that as a consequence, from a political perspective 'hate can never be good' (2002: p. 1): 'it can transform conflicts which in any society are simple, ordinary and unavoidable into major confrontations whereby the annihilation of hated others becomes a necessary and inescapable goal' (p. 60).

What are the similarities and differences between reactionary hatred, instrumental in oppressing minorities and maintaining social hierarchies, and an affect such as misandry? Misandry, or the hatred of men, is targeted against a group that is placed in a (relative) position of power and privilege. As such, it is significantly different from the emotions described by Ahmed and Lorde. Reversed hatred (or hatred against a dominant group), unlike reactionary hatred, is more likely to challenge the existing economy of power and vulnerability than to reinforce it. However, even when directed against dominant groups rather than marginalized people, hatred has tended to raise suspicion among feminists.

First, feminist activists are confronted with constant allegations of misandry from their opponents: there is a continued and strong anti-feminist stereotype of feminists as man-haters, wherever 
feminist movements have been historically present. ${ }^{2}$ In France, instances of this stereotype have recently emerged in the wake of the French \#metoo movement - \#BalanceTonPorc (\#ExposeYourPig). In January 2018, Le Monde published an article signed by 100 prominent women (including famous French actress Catherine Deneuve) advocating for a 'freedom to pester (women)' (liberté d'importuner): 'As women', they wrote, 'we do not recognize ourselves in this feminism which goes beyond denouncing abuses of power to turn into a hatred of men and sexuality'3 (Collectif, 2018). Other social actors use the 'feminists hate men' rhetoric for an even much more explicit anti-feminist purpose. On the occasion of March 8th 2020, Valeurs Actuelles, an unabashedly and virulently far-right French magazine, drew a portrait of six prominent activists (depicted as 'the new feminist hags') - two of them criticized for their 'hatred of men' and their 'man-hating speeches' (Clément et al., 2020). Finally, 'misandry' has been one of the favoured arguments of masculinist movements since the second wave. The word is used in order to describe men as victims of a tyrannical project aimed at establishing a society in which women dominate men, sometimes associated with 'aggressive lesbianism' (Dupuis-Déri, 2012; Dupuis-Déri and Blais, 2015, p. 102). These uses of hate as an argument to discredit and raise hostility against feminism are not new. 'The stereotype has hardly been renewed since the end of the 19th century', stresses historian Christine Bard, and since the suffragist movements, feminists have been repeatedly accused of hating men (based on their supposed lesbianism) and despising them in their advocacy for 'female superiority' (Bard, 1999: pp. 305-308). She emphasizes the persistence of the stereotype of feminists as man-haters, which periodically resurfaces as an element of anti-feminist backlash rhetoric. No wonder feminists reject misandry, thereby refusing an antifeminist discourse intended to bait them into a degrading stereotype.

Second, many feminist theorists have successfully argued that the ontological consequences of hatred can prove hard, if not impossible, to erase. This dimension seems to be incompatible with feminism as a political and theoretical project of de-essentializing social identities and interactions. Many post-structuralist feminists emphasize that defining men as an essential enemy has the consequence of grounding feminism on an idealized community of women - a representation that tends to reinforce gender normativity and to obscure the ways some women can themselves embody and/or side with the oppressors. First, feminist misandry is often incorporated into arguments that tend to enforce gender categories as binary, rigid and normalizing devices. ${ }^{4}$ As such, many feminists have regarded hatred of men as contrary to their emancipatory agenda (Elam, 1994: pp. 106-108; Hekman, 2000: p. 295). Second, feminist misandry regularly comes with the prioritization of anti-sexist struggle over other types of emancipatory movements, sexism being defined as the most fundamental oppression, thus minimizing the effects of other power relations. bell hooks, for example, criticizes bourgeois white women's assertions that 'men are the enemy', a claim that merely '[deflects] attention away from their support of continued exploitation and oppression' (hooks, 1984: pp. 68-69). From a deconstructivist perspective that aims to criticize the essentialist presuppositions of feminist thought, hatred of men thus appears as a feeling that inevitably leads to political dead-ends.

2 For feminist movements in France, see Bard (1999). For the way feminists were stereotyped as 'man-hating, ballbusting, selfish, hairy extremists' in mass media in the US during the 1960s and 1970s, see Douglas (1995: p. 7). 3 All the original translations in this article are mine.

4 Such uses can be found in cases of naturalizing descriptions of sexual difference within second-wave radical feminism in the United States: for instance, feminist activist Jill Johnston explicitly refers to men as 'biological aggressors' (Johnston, 1973: p. 165). 
I contend that these criticisms from feminist theorists are fully relevant: they successfully expose the shortcomings of misandry when defined as a political project by feminist activists and theorists. By political project, I mean a predetermined set of goals, values or practices, used as the premises or the 'foundations' of political action (Butler, 1995; Elam, 1994: p. 108). However, I argue that these discussions often miss an important point. First, references to hatred are rare and usually poorly detailed; when addressed, misandry is at best briefly dealt with in a few lines. These few discussions are not enough to fully account for the emotional negativity that runs through the positions taken by some feminists, such as Coffin or Harmange, or Solanas and her French followers during the women's movements of the 1970s, which I will address below. Hate is embarrassing to the point that feminists seem unwilling to theoretically engage with it. In this regard, feminist affect studies would benefit from taking the same negative turn as queer studies (Halberstam, 2011). I suggest that 'dirty' (Ngai, 2005) or anti-relational (Bersani, 1987) feelings that challenge humanist conceptions of subjectivity and politics (Edelman, 2004) are worth being looked at thoroughly.

Second, it is crucial to reflect on this issue if we are to exhibit a number of structurally silenced narratives within French feminism. Ilana Eloit shows just how central accusations of misandry are to heteronormative French feminist rhetoric against lesbians: charged with destroying 'a natural harmony between men and women' (Eloit, 2019: p. 382), she contends their dissident voices have been erased from mainstream French feminist historiography. Reflecting on misandry in feminist discourse I also aim at deactivating heteronormative feminist narratives: misandry is part of feminist emotional past and present and not the exclusive prerogative of the abject figure of the 'hysterical dyke' (p. 384).

Finally, anti-essentialist critics of man-hating generally do not engage with the first kind of criticism I described above: the rejection of misandry as an anti-feminist stereotype. Yet in this article I will show that in a seemingly paradoxical way the anti-feminist allegations of misandry provide precious insights into some feminists' reclaiming of man-hating. I defend that misandry does not necessarily entail an essentialist political project aimed at establishing an idealized community of women that erases power relations between women as well as gender normativity from feminist narratives and representations. If language - in the broad sense of a set of meanings is to be defined as a power device, which structurally prevents marginalized subjects from speaking out and voicing their demands, feminist misandry can then be read as a contextual and sometimes enabling discursive strategy.

\section{Stigma reversal: can misandry become a feminist discursive strategy?}

Let's start again from this simple statement: anti-feminists routinely stereotype feminists as manhaters. This stereotype amounts to a stigma, more specifically a discursive device that structurally renders the voices of feminists inaudible. Drawing from Judith Butler's works on injurious speeches, I will discuss the strategy of stigma reversal and suggest that some feminists may have claimed misandry in order to take back the discursive agency they have been deprived of and negotiate with a set of meanings that tends to reduce them to silence and shame.

Following sociologist Erving Goffman's definition, I suggest to define misandry as a stigma: something that causes, within a given social interaction, the discrediting of an individual's social 
identity; the social repartition of credit and discredit drawing the boundary between individuals considered normal and those deemed deviant. Among the different types of stigma defined by Goffman are thus 'domineering or unnatural passions', these being inferred from 'homosexuality and radical political behaviour' (Goffman, 1986: p. 13). Similarly, feminism is seen as the cause or the manifestation of deviant or 'unnatural' affects of hatred some women are believed to feel and that result in producing them as abnormal. Social processes of stigmatization also systematically raise strategic issues of 'stigma management': stigmatized individuals have to negotiate their assigned social identity so as to lessen 'the discrepancy between virtual and actual social identity' (Goffman, 1986: pp. 11-12), that is, the gap between one's individual sense of self and the way social frames of perception portray them.

I contend that following this definition, speeches about 'man-hating' attach a stigma to specific groups of women. This is, for example, the case of lesbians whose supposed hatred of men is a stereotype routinely involved in legitimizing lesbophobic violence and discrimination. Historically, this lesbophobic stigma is closely associated with anti-feminist rhetoric, the epithet 'lesbian' being itself used as a stigma directed against feminists. Feminists are accused of being lesbians and thus, implicitly, man-haters in order to cast discredit on their struggles and their claims. In other words, this is a case of transitive stigmatization: feminists are discredited in mainstream narratives because of their association, within those very narratives, with a group perceived as deviant. Thus, in the case of French feminist movements of the 1970s, it was not uncommon for feminists to participate more or less openly in the stigmatization of lesbians, in order to negotiate their own inclusion in the category of people who are socially constructed as normal (Eloit, 2018). Secondly, the anti-feminist 'feminists-hate-men' discourse can also arise regardless of references to lesbianism, and is then founded upon representations that associate feminism with a range of 'passions' that are deemed 'unnatural' when experienced by women (frustration, hysteria, violence, etc.).

Following Judith Butler, I suggest this stigma works as a discursive device which conveys and enforces norms, whose effect is to establish specific bodies as abject - as non-subjects (Butler, 1995: p. 46). Misandry, the 'unnatural passion' that afflicts feminists in anti-feminist representations, is instrumental in building bodies and voices that do not 'count' (Butler, 1993) (deviant women, lesbians, etc.). In other words, the case of feminist misandry must be considered as part of a larger discussion about the possibilities of voicing a critical stance within a social space of meanings which is primarily shaped by dominant groups' representations and interests (Lorde, 1984a). How do feminists manage the stigmatizing effects of an affect - hatred of men? How do they negotiate their own agency regarding the negative frames through which they tend to be perceived? What strategies can feminists use in order to act against the degrading effects of the stigma? For feminists, then, misandry raises first and foremost a strategic and discursive issue: what can one do with words?

In Excitable speech, Butler focuses explicitly on such verbal strategies, language and subjectivity being inescapably shaped by those injurious words and their performative effects. She contends that the power of such words is by no means unequivocal: the injury 'may appear to fix or paralyze the one it hails, but it may also produce an unexpected and enabling response' (Butler, 1997: p. 2). Some practices are likely to resignify the insult insofar as to contextually reverse its effects. In 'Critically Queer' she examines this possibility via the practice of stigma reversal, when the injured subject incorporates this very same stigma into their own self-discourse and turns it into a positive 
component of their social and political identity. In the process '[a] term that signalled degradation [is] turned (...) to signify a new and affirmative set of meanings' (Butler, 1999a: p. 570). Drawing on Butler's analysis, I contend that many feminist uses of misandry are practices of stigma reversal. When feminists call themselves 'man-haters' they resignify the injurious term in order to undermine the way the word was supposed to work in the first place - namely, as a 'paralyzing slur' (p. 570).

\section{Valerie Solanas in Paris: an 'unfamiliar scum's}

To further this hypothesis, I hereby focus on a historical case study: the appropriation of Valerie Solanas' SCUM Manifesto by French feminists of the second wave. After a brief historical review of the role of misandry within French women's movements of the 1970s, I will turn to the reception of SCUM by French radical feminists. Such discourses, I will show, are both prominently metaphorical and empowering in their effects; as such they exhibit features that are characteristic of strategies of stigma-reversal.

In France, second-wave feminist movements' earliest premises can be dated back to May 1968 . Historians usually agree in considering that the founding event of the movement was a parody ceremony under the Arc de Triomphe in Paris, in August 1970, and define as its end 1979, a year of great tensions within the movement (Picq, 2011). In her reference book on misandry within the French Women's Liberation Movement (or MLF, for Mouvement de Libération des Femmes), historian Colette Pipon observes that the word 'misandry' appeared for the first time in several dictionaries during the 1970s (2014: p. 16), as if the rise of a feminist movement in turn produced stigmatizing terms designed to silence it. There were indeed many denials of the stereotype of feminists as man-haters in the feminist press of the period. For example, in La voix des femmes (Women's voice), one of the first newspapers of the women's movement in Lyon, some of the contributors seemed anxious to justify that their political choice to organize exclusively among women is not based on a rejection of men: ${ }^{6}$ 'it should not be believed that the women of the MLF are against males,' they stated (Jacquemart and Masclet, 2017: p. 224).

However, Pipon also made it very clear that, although adopted by a minority, man-hating discourse was a component of MLF activists' rhetoric, largely among the trend closely identified with radical feminism. ${ }^{7}$ Like US radical feminist Pamela Kearon (1970: p. 84), some explicitly advocated for an affirmative use of the word 'misandry,' such as an anonymous contributor to the feminist journal Le Torchon Brûle in 1971:

Anyway, guys are misogynists, okay; but I, since I was born, I've been, uh, the same as misogynist; the equivalent. (...) With friends we started looking everywhere, in the dictionary, the big one, the small one, everywhere in the literature, nothing. In other words, in this world made and built for them, men have the right to dislike women.

5 A translation of the title of Cathy Bernheim's text I quote below. See Bernheim (2009 [1971]).

6 A concern that is largely understandable when one considers the hostility they had to face from their male activist counterparts in leftist organizations. For an example of this leftist male hostility, see the humorous text written by a group of feminist activists 'Contre le terrorisme mâle' ('Against male terrorism'), initially published in L'idiot international, ${ }^{\circ}$ 7-8, July-August 1970, reproduced in Kandel (1992: pp. 246-248).

7 The Parisian second-wave feminist trend called 'revolutionary feminist,' which included some of the most influential leaders of the movement, endorsed political positions that strongly resembled radical feminism. See Picq (2011).

8 Le torchon brûle is one of the main journals of the MLF, issued from 1970 to 1973 . Contributors are always anonymous. 
Women, of course, have no right to take a dislike to them (...). It is up to us to invent this word (...).

Instead of denying that they hate men, some second-wave feminists did actively claim it. However, Pipon defends that such hatred of men is fundamentally different from misogyny. First, misogyny is a violent affect aimed at one's destruction, submission or oppression; yet 'as a matter of fact, the protagonists of the Movement made no attempt to destroy or oppress men' (Pipon, 2014: p. 204). Indeed, these movements were predominantly non-violent in nature. Feminists willingly claim their refusal of physical violence (Zancarini-Fournel, 2005), and some of the same feminists who advocate misandry had made non-violence a decisive argument in favour of their struggle: there were no 'castrated, mutilated or stoned males in the name of the victims of sexism' (Bernheim et al., 2009: p. 7). In a word, feminist misandry cannot be associated with a definition of hatred that we may call destructive: a desire to actually harm, destroy or submit men.

In this respect, this affect in no way matches the affective drive I described above earlier using Ahmed, Lorde and Le Cour Grandmaison: feminist misandry exhibits characteristics that tend to profoundly alter the meaning of the hatred such speeches are supposed to carry. Secondly, Pipon argues that hatred of men as expressed by 1970s feminists is what she calls a 'response-hatred:' a defensive reaction towards misogyny (Pipon, 2014: p. 204). According to her, misandry is contextual and understandable only as a discursive strategy aimed against a primary affect - hatred and contempt for women in patriarchal societies. While I agree with her analysis of misandry as a contextual strategy, I argue that the target of such strategy is not so much misogyny but the antifeminist stigma of feminists as man-haters. Feminists call themselves 'man-haters' (misandres) in order to counter the stigma and neutralize its restraining and inhibiting effects on their actions and speeches. Thus, I disagree with Pipon, who argues that second-wave feminists' misandry led the movement to a 'dead-end' (p. 175). In her view, aggressive practices and discourse among some MLF activists have discouraged later generations of activists from identifying as feminists (p. 203), and she goes so far as to imply that for this reason radical lesbianism prompted the demise of the movement (Eloit, 2018: p. 263). On the contrary, I argue that the inhibiting effects of such a stigma on feminist politics - the aggressive, castrating and hateful feminist you should at all cost avoid to become - can be managed, if not neutralized, by means of feminist misandry.

My analysis is based on my reading of the French appropriations of Valerie Solanas' SCUM Manifesto, which in spite being extremely marginal in the French context is emblematic the internal misandry of second-wave feminist movements, or misandry claimed by feminist activists. This text reached sudden notoriety after Solanas shot Andy Warhol in 1968, becoming overnight 'something of a cause celebre among radical feminists' in the United States ${ }^{9}$ and bringing controversies within women's liberation groups in the US (Echols, 1989: p. 105). With a sharp humour and an especially imaginative verbal violence, she depicts men as despicable, repugnant, and biologically inferior beings (Solanas, 2004 [1977]). In France, Solanas' deeds were far from making headlines as they did in the United States. The SCUM Manifesto, however, did come across the Atlantic, which is not surprising considering that the writings of the women's movement in the United States were widely

9 Influential feminist activists Ti-Grace Atkinson and Florynce Kennedy described her as 'the first outstanding champion of women's rights' and 'one of the most important spokeswomen of the feminist movement' (Fahs, 2008, p. 596). 
read within the nascent French MLF in $1970 .{ }^{10}$ Translated by a feminist activist, Emmanuèle de Lesseps, with a front cover that described SCUM as 'the first manifesto for women's liberation' (Solanas and Rochefort, 1971), the manifesto quickly began to capture French feminists' imagination as well. Such is the success of the manifesto that it quickly ran out of print, and many feminists complained that they couldn't get a copy: filmmaker Carole Roussopoulos and actress Delphine Seyrig then came up with an ingenious way to share its content, shooting a short film with an out loud reading of the manifesto (Roussopoulos and Seyrig, 1976; Fleckinger, 2009).

Of course, because Valerie Solanas has never been part of the feminist movement and because of the biting irony of her writing these feminist appropriations are always limited: her manifesto can just as easily be appropriated by anti-feminists as by feminists. ${ }^{11}$ Some may find there the echo of their own anti-feminist fantasies and a satisfying confirmation of what they project upon feminist movements: a political project directed towards the oppression of men by women. ${ }^{12}$ Butler stresses it is never certain that the strategy of stigma reversal will work and 'the term [can] overcome its constitutive history of injury'. 'Neither power nor discourse are rendered anew at every moment' she recalls; 'they are not as weightless as the utopics of radical resignification might imply' (Butler, 1999a: pp. 570-571). Using the concept of strategy, I thereby emphasize that the effects of misandry are always contextual, in order to avoid unilateral and essentializing interpretations.

Nevertheless, Valerie Solanas' manifesto had a deep and significant impact on some of the French women's movement activists in the 1970s. Those who read and disseminated the text were especially challenged, inspired and influenced by two specific dimensions: the fantasy of a world without men and a political imagery of unabashed violence. These privileged topics reflect two important characteristics of misandry when claimed by these feminists: a prominently metaphorical or symbolic dimension, and empowering effects.

First, some see Solanas' text as a vehicle for conveying and exploring specific fantasies, fictitious representations that are not intended to come true (as they are not actual political projects) but rather to foster the political imagery of the movement. Feminist and lesbian activist Cathy Bernheim ${ }^{13}$ thus wrote a text about SCUM in which she mentioned a 'collective fantasy:' the cathartic fiction of the outright demise of men. 'When they will read SCUM, men [...] will ask us, without believing it: is it true that you want a world where we would not exist? We will answer them, women, my sisters, that we do not desire such a world: we are plotting it' (Bernheim, 2009 [1971]: pp. 257258). In spite of the determination she expresses, the world without men she refers to is purely a fantasy: as Pipon puts it 'while the discourse is sometimes provocative, even aggressive towards

10 One of the first sets of texts written in France by second-wave feminists about the movement, an issue of leftist review Partisans, bears witness of this influence (Libération des femmes, année zéro, $\mathrm{n}^{\circ} 54-55,1970$ ). About the third of the articles displayed in this issue are translations of writings by US feminists such as Roxanne Dunbar, Carol Hanisch, Anne Koedt, etc.

11 As an illustration of the ambiguous ways Solanas' text captures the imagination, the foreword of the 1998 French edition of the manifesto was written by Michel Houellebecq, a prominent writer well known for his anti-feminism.

12 For example, such is the case of French writer Robert Merle, who authored in 1974 a science fiction novel depicting a tyrannical matriarchy in which women deprive men of their freedom, sexually and economically exploiting them (Merle, 1974). The author takes the feminist movements of the early 1970s as a source of inspiration, having read SCUM with great interest (Wattel, 2018: p. 94; pp. 247-248).

13 An early activist within the MLF and one of the founders in 1971 of the Gouines rouges (Red dykes), a lesbian feminist group, she is the author of a book that recounts her memories of the movement (Bernheim, 1983). 
men, (...) the radicality is contained within the realm of feminist thought and words and violence is limited to the field of imagination' (Pipon, 2014: p. 205). Historian Michelle Zancarini-Fournel also highlights the 'symbolic' character of the violence perpetrated by feminist activists in the 1970s: 'Women's weapons are provocation, derision,' they belong to the domain of words and spectacle (Zancarini-Fournel, 2005). In a word, the negative and violent affect such appropriations of Solanas exhibit aims at something which is not so much material as symbolic. Taking up the way the subtitle of the SCUM was originally translated in many languages, ${ }^{14}$ the French followers of Solanas do not so much advocate for the actual annihilation of men as they call for a fictional representation they consider to have liberating effects. Quoting the vocabulary used by Liliane Kandel, a feminist activist of the 1970s, I suggest that feminist misandry can thus be read as a 'metaphor', ${ }^{15}$ i.e. as a figure of speech (Kandel, 1992). Much like a stylistic device indeed, misandry is not to be interpreted literally; the point is rather to question the desired effect of the verbal image.

The metaphorical dimension of feminist misandry has empowering effects for feminists, in particular through the discursive appropriation of unabashed and cathartic violence. Feminists such as Christiane Rochefort, a famous novelist and early member of the MLF, draw upon the imagery of physical violence that infuses the manifesto in order to symbolically reclaim an agency that patriarchal oppression deprives women of. 'There comes a time when you need to pull the knives,' she writes in the powerful foreword to the 1971 French edition of the manifesto. To her, violence is necessary because within mainstream social frames of perception the victimhood of women is merely viewed as a 'natural fact' and not as a social prejudice that needs to be addressed. Claiming victim status and acting as such is then tantamount to "blending into the background set by the oppressor'. As a result, 'the knife is the only way to define oneself as oppressed': violence is the only language likely to voice oppression in a way the oppressor can hear and pay attention to (Rochefort, 2005 [1971]: p. 3). In a word, misandry is the one and only kind of political speech women have which may not be a priori made helpless, silent and ineffective. SCUM is perceived by feminists like Rochefort as an unordinary and inspiring text charged with an agency women's voices are usually robbed of.

How can metaphorical hatred be empowering for feminists and in which place does fictional violence become agency? I argue that the use of misandry as a discursive strategy of stigma reversal is the very reason of such connection. As Avital Ronell puts it, what feminists owe to Solanas is having 'plug[ged] the kind of speech that counters while resembling hate speech' (Ronell, 2004). The SCUM Manifesto served as an opportunity to express a je ne sais quoi they were both struggling and eager to voice: to provocatively reverse the negative image their detractors reflected back to them. Cathy Bernheim acknowledges such a debt when she fiercely claims: 'Yes, we are what you say we are, we are even worse' ${ }^{16}$ (Bernheim, 2009[1971]: p. 259).

14 Dana Heller defends that the meaning of the acronym, Society for Cutting Up Men, was originally a mere literary device (Heller, 2001). In the foreword she writes to the 2004 edition of SCUM, Avital Ronell traces how throughout the translation process in various languages - German (1969), Spanish (1977), Italian (1994) and Czech (1998) - the subtitle has been "gloss[ed] on [...] with annihilating precision" (Ronell, 2004).

15 A phrase she initially uses in reference to non-mixed practices within the MLF.

16 In much the same way, in 1970, Robin Morgan (a prominent US second--wave radical feminist) angrily writes that 'we are the women that men have warned us about' (Morgan, 1971: p. 275). 


\section{Countering respectability politics: hatred, anger and power} What's empowering about a stigma-reversal strategy such as misandry? Drawing on these French appropriations of Solanas, I hereby open up a few theoretical inquiries for reflecting on what this strategy enables feminists to overcome and what kind of possibilities it brings into existence.

First, I contend that the strategic use of misandry can help break with the overly restrictive constraints of the politics of respectability and their paralyzing effects on the movement. The concept of 'respectability' is used by sociologist Beverley Skeggs in her work on white workingclass women in the United Kingdom (Skeggs, 1997). She shows that in this context, femininity works as a display consciously performed by women in order to counter class stigmatization. When used regarding social struggles, the concept of 'respectability politics' refers to a strategy that consists in an emphasis on appearances and reputation, thus attempting to deactivate the negative representations attached to a minority in struggle in order to get their demands heard (Higginbotham, 1993). However, this strategy has serious negative consequences for such groups. Dealing with the case of Black activism, E. Frances White thus shows that such politics gives rise to dangerous forms of gatekeeping and the silencing of difference (White, 2001). Works on LGBTQI activism have also brought to light the effects of this strategy on gender and sexual minorities (Matsick and Conley, 2015) and the ways they tend to reinforce typical oppressive feelings such as shame or fear (Robinson, 2012). Applied to feminism, respectability politics is a collective endeavour to meet the norms of femininity or 'good' womanhood in order to make claims about equality heard and accepted.

Claiming misandry, on the contrary, can be read as a discursive strategy directed against injunctions to respectability. For example, in this way one can interpret the fascination Valerie Solanas' eccentric manifesto produced on second-wave feminists. In their eyes, Valerie Solanas embodies a provocative and conscious refusal to answer anti-feminist man-hating-baiting with a defensive stance of denial: 'She laughs in the face of apologetic, we-don't-really-hate-men, we're-notlesbians, we-shave-our armpits, we're-not offensive feminism. She arouses the central anxieties of the feminist movement [...]' (Fahs, 2008: p. 613). Thus, 50 years after French feminists first discovered Solanas' SCUM Manifesto, Pauline Harmange confirms that she finds misandry liberating and even exhilarating: 'I see misandry as a way out. A way to exist outside the box, a way to say no with each breath. Hating men as a social group and in many cases as individuals as well brings me great joy - not only because I'm a crazy old cat lady' (Harmange, 2020: p. 14).

Moreover, feminist respectability politics have especially damaging effects on the expression of anger. Being angry is indeed radically incompatible with standards of femininity, and thus concerns for appearances and respectability unavoidably take part in policing feminist expressions of negative and oppositional feelings. For example, French author and blogger Valérie Rey-Robert points out that the discourse of female rape survivors about their own experience is strongly impacted by the negative stigmatization of anger; they feel compelled to 'avoid any aggressive or misandre (man-hating) remarks that, as we know, could scare [men] away' (Rey-Robert, 2020). Alice Coffin thus claims the heritage of Solanas when she clarifies the criticism she makes of the 'not-all-men' rhetoric.

I don't know what extra amount of men would be necessary to stop condemning 'men' and start to write 'certain men,' 'some men,' 'a few men,' but I know we are talking about teratons, not grams. This injunction not to generalize locks up public speaking out but not private conversations between feminists. Let them know that [the conversations] 
I hear on a daily basis are variations on Valerie Solanas' words in the SCUM Manifesto: 'The male has a negative Midas Touch - everything he touches turns to shit.' So I'm going to generalize. It's not as if men feel bad about doing exactly the same thing [...]. Yes, then, I'll say 'men'. (Coffin, 2020: 196)

What I suggest here is that in opposing respectability politics, misandry as a discursive strategy and a metaphoric and symbolic hatred of men opens up new possibilities for the feminist voicing of anger. In a word, maybe hatred should not systematically be opposed to anger, if anger is to be considered as a valuable political resource for feminism (Ahmed, 2013; Lorde, 1984b). Provocative expressions of hate are sometimes one of the 'conditions of possibility for feminist anger to get a just hearing' (Ahmed, 2013: p. 177).

\section{Conclusion}

When it comes to feminists, hatred is primarily a stigma, and this is precisely the reason why claiming such a violent affect can, on occasion, become a way to reclaim agency. Therein lies a paradox: because feminists tend to be silenced by accusations of hating men, symbolic manifestations of misandry can perhaps be useful to feminists. Without denying the multiple political dead-ends hatred of men can push feminism into, it therefore seems important to suggest that feminist misandry can also, in a very contextual way, become empowering for feminists as a strategy of stigma reversal. The outcome of the strategy is such that this hatred, transformed into a figure of speech that no longer has much to do with the original urge to destroy, opens up possibilities to reject the rules of mainstream discourse and the injunctions of respectability politics.

\section{References}

Ahmed S (2013) Feminist Attachments: The Cultural Politics of Emotion. New York: Routledge.

Anonymous (1971) Dans les HLM. Le torchon brûle 2: 10.

Bard C (1999) Un siècle d'antiféminisme. Fayard, Paris.

Bernheim C (2009[1971]) SCUM ou l'écume inconnue. In: Bernheim C, Kandel L, Picq F et al. (eds) Mouvement de libération des femmes: textes premiers. Paris: Stock, pp. 255-261.

Bernheim C (1983) Perturbation, ma sœur: naissance d'un mouvement de femmes (1970-1972), Paris: Seuil.

Bernheim C, Kandel L, Picq F et al. (eds) (2009) Mouvement de libération des femmes: textes premiers.

Bersani, Leo. 1987. Is the Rectum a Grave? October 43.

Butler J (1993) Bodies that Matter: on the Discursive Limits of "Sex." New York: Routledge.

Butler J (1995) Contingent Foundations: Feminism and the Question of "Postmodernism." In: Butler J and Scott J (eds) Feminist Contentions: A Philosophical Exchange, Thinking Gender. New York: Routledge.

Butler J (1997) Excitable speech: a politics of the performative. New York: Routledge.

Butler J (1999a) Critically Queer. In: Wolfreys J (ed) Literary Theories: A Reader and Guide. Edinburgh: Edinburgh University Press, pp. 570-586.

Butler J (1999b) Gender trouble : feminism and the subversion of identity. New York: Routledge.

Cappelle L (2021) With 'I Hate Men,' a French Feminist Touches a Nerve. The New York Times, January $10^{\text {th }} 2021$, sect. Books (accessed 17 February 21).

Clément $\mathrm{N}$ et al. (2020) Au bal des harpies. Valeurs Actuelles, 12 March, 26. 
Coffin Alice (2020) Le génie lesbien. Paris, France: Grasset.

Collectif (2018) Nous défendons une liberté d'importuner, indispensable à la liberté sexuelle. Le Monde, 9 January.

Douglas S (1995) Where the Girls Are: Growing Up Female With the Mass Media. New York: Times Books.

Dupuis-Déri F (2012) Le discours de la « crise de la masculinité » comme refus de l'égalité entre les sexes: histoire d'une rhétorique antiféministe. Cahiers du Genre 52(1): 119-143.

Dupuis-Déri F and Blais M (eds) (2015) Le Mouvement masculiniste au Québec: l'antiféminisme démasqué. Montréal: Les Éditions du remue-ménage.

Echols A (1989) Daring to be bad: radical feminism in America 1967-1975. Minneapolis, London: University of Minnesota Press.

Edelman L (2004) No future: queer theory and the death drive. Electronic resource. e-Duke Books Archive, Series Q.

Elam D (1994) Feminism and deconstruction: Ms. en abyme. London, New York: Routledge.

Eloit I (2018) Lesbian Trouble: Feminism, Heterosexuality and the French Nation (1970-1981). $\mathrm{PhD}$ Thesis, LSE - London School of Economics and Political Science, UK.

Eloit I (2019) American Lesbians Are Not French Women: Heterosexual French Feminism and the Americanisation of Lesbianism in the 1970s. Feminist Theory 20(4): 381-404.

Fahs B (2008) The Radical Possibilities of Valerie Solanas. Feminist Studies 34(3): 591-617.

Fleckinger H (2009) Une révolution du regard. Entretien avec Carole Roussopoulos, réalisatrice féministe. Nouvelles Questions Feministes 28(1): 98-118.

Goffman E (1986) Stigma: notes on the management of spoiled identity. New York: Simon \& Schuster.

Halberstam J (2011) The queer art of failure. Durham: Duke University Press.

Harmange P (2020) Moi les hommes, je les déteste. Paris, France: Éditions du Seuil.

Harmange P and Lehrer N (2020) I Hate Men. London: Fourth Estate Ltd.

Hekman S (2000) Beyond identity: Feminism, identity and identity politics. Feminist Theory 1(3): 289-308.

Heller D (2001) Shooting Solanas: Radical Feminist History and the Technology of Failure. Feminist Studies 27(1): 167.

Higginbotham EB (1993) Righteous discontent: The women's movement in the Black Baptist Church, 1880-1920. Cambridge, MA: Harvard University Press.

Holmes M (2004) Feeling Beyond Rules: Politicizing the Sociology of Emotion and Anger in Feminist Politics. European Journal of Social Theory 7(2): 209-227.

hooks b (1984) Men: Comrades in Struggle. In: Feminist Theory from Margin to Center. Boston: South End Press, pp. 68-83.

Jacquemart A (2015) Les hommes dans les mouvements féministes: socio-histoire d'un engagement improbable. Rennes: Presses universitaires de Rennes.

Jacquemart A and Masclet C (2017) Mixités et non-mixités dans les mouvements féministes des années 1968 en France. Clio 46(2): 221-247.

Johnston J (1973) Lesbian nation: The feminist solution. New York: Simon and Schuster.

Kandel L (1992) La non-mixité comme métaphore. In: Baudoux C and Zaidman C (eds) Égalité entre les sexes: mixité et démocratie. Paris: L'Harmattan.

Kearon P (1970) Man-Hating. In: Koedt A and Firestone S (eds) Notes from the Second Year: Women's Liberation. New York: Radical Feminism.

Le Cour Grandmaison O (2002) Haine(s). Presses Universitaires de France. 
Lorde A (1984a) The Master's Tools Will Never Dismantle the Master's House. In: Sister Outsider: Essays and Speeches. Trumansburg: Crossing Press, pp. 110-114.

Lorde A (1984b) The Uses of Anger: Women Responding to Racism. In: Sister Outsider: Essays and Speeches. Trumansburg: Crossing Press, pp. 125-133.

Matsick JL, Conley TD (2015) Maybe “I Do," Maybe I Don't: Respectability Politics in the SameSex Marriage Ruling. Analyses of Social Issues and Public Policy 15(1), 409-413.

Merle R (1974) Les hommes protégés. Paris: Gallimard.

Morgan R (1971) Goodbye to All That. In: Tanner L (ed) Voices from women's liberation. New York: New American library.

Ngai S (2005) Ugly Feelings. Cambridge: Harvard University Press.

Phelan S (1989) Identity politics: lesbian feminism and the limits of community. Philadelphia: Temple University Press.

Picq F (2011) Libération des femmes: quarante ans de mouvement. Brest: Dialogues.

Pipon C (2014) Et on tuera tous les affreux: le féminisme au risque de la misandrie, 1970-1980. Rennes: Presses universitaires de Rennes.

Rey-Robert V (2020) Des femmes violées et de leur indignité. In: Crêpe Georgette. Available at http://www.crepegeorgette.com/2020/02/06/femmes-violees-indignite/ (accessed 18 May 20).

Robinson BA (2012) Is This What Equality Looks Like?: How Assimilation Marginalizes the Dutch LGBT Community. Sex Res Soc Policy 9(4), 327-336.

Rochefort C (2005[1971]) Définition de l'opprimé. In: Solanas V, Lesseps E (trad) SCUM Manifesto. Paris: Zanzara athée. Available at https://www.infokiosques.net/IMG/pdf/SCUM_v2005-pageparpage.pdf (accessed 29 March 21).

Ronell A (2004) Deviant Paybacks: the Aims of Valerie Solanas. In: SCUM Manifesto [epub]. New York: Verso.

Roussopoulos C and Seyrig D (1976) S.C.U.M. Manifesto.

Skeggs B (1997) Formations of class and gender: becoming respectable. Thousand Oaks: SAGE. Solanas V (2004[1977]) SCUM manifesto [epub]. New York: Verso.

Solanas V and Rochefort C (1971) SCUM. de Lesseps E (tran). Paris, France: La nouvelle société. Spelman E (1996) Anger and Insubordination. In: Garry A and Pearsall M (ed) Women, Knowledge and Reality: Explorations in Feminist Philosophy. New York: Routledge.

Wattel A (2018) Robert Merle, écrivain singulier du propre de l'homme. Presses Universitaires du Septentrion.

White EF (2001) Dark continent of our bodies: Black feminism and the politics of respectability. Philadelphia: Temple University Press.

Zancarini-Fournel M (2005) Stratégies de distinction par la voix et le geste: provocations et violences symboliques des femmes dans les manifestations des années 68. In: Bourdin P, Bernard M and Caron JC (eds) La voix \& le geste: une approche culturelle de la violence socio-politique. Clermont-Ferrand: Presses universitaires Blaise-Pascal. 